Feature Article

\title{
Development of a Timber Property Classification Based on the End-Use with Reference to Twenty Sri Lankan Timber Species
}

\author{
N.D. Ruwanpathirana*
}

State Timber Corporation, Sri Lanka

\begin{abstract}
An investigation was carried out on selected 20 timber species of Sri Lanka to study different wood properties, i.e., wood density, modulus of rapture, modulus of elasticity, compression parallel to grain, shrinkage/movement, workability (sawing, nailing, sanding and finishing), treatability of preservative, timber durability, timber texture by vessel diameter and some gross properties, timber colour and present timber uses. Based on the results, an attempt was made to classify the studied timber species into property levels. The final objective of this study was to develop relationships between the end-uses of timber and their property requirements and levels with reference to 20 Sri Lankan timber species.

Timber selection for the use in Sri Lanka is species-oriented and sometimes it is based on the traditional use. Based on wood properties of 20 Sri Lankan timber species selected, an attempt was made to recognise the most important wood properties and their levels to develop a four end-use property classification. In general, the proposed end-use property classification in this study could be differentiated as (i.) for building construction, (ii.) for furniture and joinery (iii.) for light construction, and (iv.) for miscellaneous uses. Among the selected timber species, Dipterocarpus zeylanicus is eminently suitable for under-water work. Eucalyptus microcorys is regarded as one of the best timbers for dancing floors. These specialty and causative factors of timber, however, must be explored and documented in order to prepare end-use property classification for miscellaneous use.
\end{abstract}

\section{Introduction}

Sri Lanka a small island of 6,561,000 ha, posses a significant biodiversity along with various tree species. Total natural forest cover in Sri Lanka is 1,951,472 ha which consists $1,521,987$ ha of closed canopy forests and 429,485 ha of open canopy forests. There are over 350 timber tree species present in these forests and other crown lands. Present annual timber consumption in Sri Lanka is 1.6 million $\mathrm{m}^{3}$ from which around $10 \%$ is supplied by imports. Forest plantations and homegardens that have the potential of producing good quality timber, contribute about $10 \%$ and $40 \%$ of national timber requirements respectively.

\footnotetext{
*Correspondence: nimalruwan@gmail.com

Tel: +94112885853

ISSN 2235-9370 Print/ISSN 2235-9362 Online (C) University of Sri Jayewardenepura
} 
Wood properties vary with timber species and each and every property may bring a unique value and important feature to timber and its end-use. This variability of timber serves a variety of uses and if a particular timber is good for one purpose it may not be useful for another purpose. In general, selection of timber species for particular end-use depends on technical performance of timber such as durability, movement, strength, stiffness and toughness, permeability and ease of processing. Lack of knowledge on mechanical properties of structural timber leads to structural application of unnecessarily high safety margins in timber design. As far as wood properties of Sri Lankan timber species are concerned, comprehensive studies were not conducted on physical properties, mechanical properties, anatomical properties, gross features, working properties, durability, timber seasoning and preservation. Timber selection for the use is species oriented, sometimes on the basis of traditional use, however, more frequently on considerations of availability, cost, size and performance. Therefore information is much useful for the selection of timber species for the end-use because an appropriate combination such technical information is often among the last to be considered at present.

An end-use property classification can be defined in the first place for building construction, furniture and joinery, light construction work and miscellaneous uses, flooring and furniture. For instance, property requirements and preferable property level for property classification for major user groups can be judged based on experience of the factors which affecting performance, and guided by standards and specifications. This paper provides most of important wood properties with its property levels such as density, some mechanical properties, natural durability and treatability, dimensional movement and seasoning properties, working properties, gross features (colour and texture). Hence using this information on property requirements for a product, it is possible to select the suitable timber species in which required technical information is available.

The objectives of the present study were to determine wood properties of 20 selected Sri Lankan timber species (Table 1), to classify the studied wood properties into property levels and to develop relationships between the end-uses of timber and their property requirement and levels with reference to twenty Sri Lankan timber species.

Table 1: List of commonly used timber species.

\begin{tabular}{llll}
\hline No & Name & Scientific name & Family \\
\hline 1 & Acacia & Acacia malanoxylon & Fabaceae \\
\hline 2 & Ginisapu & Michelia champaca & Magnoliaceae \\
\hline 3 & Grandis & Eucalyptus grandis & Myrtaceae \\
\hline 4 & Havarinuga & Alstonia macrophylla & Apocynaceae \\
\hline 5 & Hora & Dipterocarpus zeylanicus & Dipterocarpaceae \\
\hline 6 & Ketakala & Bridelia retusa & Phyllanthaceae \\
\hline 7 & Khaya & Khaya senegalensis & Meliaceae \\
\hline 8 & Kohomba & Azadirachta indica & Meliaceae \\
\hline 9 & Kolon & Adina cordifolia & Rubiaceae \\
\hline 10 & Kos & Artocarpus heterophyllus & Moraceae \\
\hline 11 & Kumbuk & Terminalia arjuna & Combretaceae \\
\hline
\end{tabular}




\begin{tabular}{llll}
\hline 12 & Liyan & Homalium zeylanicum & Salicaceae \\
\hline 13 & Lunumidella & Melia dubia & Meliaceae \\
\hline 14 & Mahogany & Swietenia macrophylla & Fabaceae \\
\hline 15 & Mee & Madhuca longifolia & Sapotaceae \\
\hline 16 & Microcorys & Eucalyptus microcorys & Myrtaceae \\
\hline 17 & Para Mara & Albizia saman & Fabaceae \\
\hline 18 & Rubber & Hevea brasiliensis & Euphorbiaceae \\
\hline 19 & Teak & Tectona grandis & Verbenaceae \\
\hline 20 & Toona & Toona ciliata & Fabaceae \\
\hline
\end{tabular}

\section{Materials and Methods}

Authentic timber samples of 20 Sri Lankan timber species were collected from the Research Division of State Timber Corporation (STC) along with fresh wood samples from the mature trees in the field. Wood samples and disks were cut from each species at breast height of the tree. The collected specimens from the two sources mentioned above were compared anatomically with each other for the confirmation of species identity. A radial strip was cut from each disk for the investigation of anatomical characteristics. Required number of timber samples with necessary dimensions were cut and removed for the measurement of specific gravity, mechanical properties, shrinkage and movement, durability testing at grave yard, boron preservation, working properties, wood texture and heartwood colour.

\subsection{Timber density}

A radial strip cut from each disk was used for the measurement of timber density. Timber density was determined on the basis of oven-dry weight and green volume. Timber density of 20 species studied were grouped into four categories as light wood $\left(<=500 \mathrm{kgm}^{-3}\right.$ at $12 \%$ moisture content), medium density wood (500-640 $\left.\mathrm{kgm}^{-3}\right)$, high density wood $\left(640-840 \mathrm{kgm}^{-3}\right)$ and very high density wood $\left(>840 \mathrm{kgm}^{-3}\right)$.

\subsection{Shrinkage and movement}

Wood specimens $(2 \times 2 \mathrm{~cm}$ in cross section and $5 \mathrm{~cm}$ long) in green state were weighed up to the accuracy of $0.001 \mathrm{~g}$ and conditioned to achieve constant weights at about $10-12 \%$ moisture and then oven-dried at $103^{\circ} \mathrm{C}$ until a constant weight was obtained. Lengths of the specimens along radial and tangential plane at green, air dry and oven dry conditions were measured and radial and tangential shrinkages were calculated. These samples, prior to use for oven dry measurement were subjected to determine the timber movement under atmospheric condition from relative humidity of $80 \%$ to relative humidity of $60 \%$. Shrinkage and movement properties levels were categorised into three groups as high $(>12 \%)$, medium $(7 \%-12 \%)$ and low $(<7 \%)$.

\subsection{Mechanical properties}

Static bending test of air-dried $2 \times 2 \mathrm{~cm}$ (cross section) and $30 \mathrm{~cm}$ long specimen was carried out using a universal test machine. Deflections and the corresponding loads were recorded and load deflection curves were prepared. Modulus of rapture and modulus of elasticity were 
calculated. Compression perpendicular to grain was also carried out by same machine using timber sample of $2 \times 2 \mathrm{~cm}$ (cross section) and $6.2 \mathrm{~cm}$ long specimen.

\subsection{Wood durability.}

Heartwood timber samples $(5 \times 5 \times 60 \mathrm{~cm})$ were buried in ground following the principle of grave yard experiment and deterioration of timber with time table were observed. Timber durability was classified as non-durable ( $<5$ years), moderately durable (5-10 years) and durable ( $>10$ years). In addition, ground survey was conducted to collect information of timber durability.

\subsection{Timber treatability with boron preservation}

Depth of penetration and retention of boron preservative were calculated after timber samples were immersed in the boron solution complying for standard procedure. Boron retention levels were classified as easy $\left(>10 \mathrm{kgm}^{-3}\right)$, medium $\left(6-10 \mathrm{kgm}^{-3}\right)$ and difficult $\left(<6 \mathrm{kgm}^{-3}\right)$.

\subsection{Wood colour}

Wood samples containing both heartwood and sapwood were used to determine wood colour according to IAWA (1989) category No. 197 to 202 by naked eye. Heartwood colour was categorised mainly into four groups, namely, (i.) basically brown or shade of brown, (ii.) red or shade of red, (iii.) yellow or shade of yellow and (iv.) white to grey. Visible differentiation of heartwood color from sapwood was also studied.

\subsection{Anatomical characteristics}

A radial strip taken from the pith to bark was used for the investigation of anatomical characteristics. These wood samples were boiled in water for about two hours to soften them. Each wood sample was shaped and sized into wood block of $2 \times 2 \times 3 \mathrm{~cm}$. Transverse, radial and tangential sections at the range of $10-15 \mu \mathrm{m}$ thickness were obtained by using a sledge microtome (Model Leica SM2000 R). The permanent slides of wood were prepared after dehydrated and stained in safranin. Sections were mounted using Canada balsam using standard procedure.

Microscopic observations of each slide were made for qualitative and quantitative analysis of parameters under the light microscope at $4 \times 10$ magnifications. Measurements on wood anatomical features were taken after photomicrographs of each slide were made by Olympus microscope and Micromertics SE Premium 4 software available in the Research

Division of STC. Measurements of tangential vessel diameter were used to determine the wood texture.

\subsection{Wood texture}

Mean vessel tangential diameter, ray width and ray height were measured in this study from which average tangential diameter of the vessel $(\mu \mathrm{m})$ was used to determine wood texture. Vessel size is primarily responsible for texture, however, in a wood with large rays and vessels of moderate size or small size, coarse texture may ensure from large rays alone. The classification given in Table 2 and ray information studied serve to indicate roughly the basis of classification. 
Table 2: Classification of wood texture.

\begin{tabular}{ll}
\hline Type of wood texture & Average tangential diameter of the vessel $(\mu \mathrm{m})$ \\
\hline Fine textured & Less than 100 microns \\
Medium textured & 100 to 200 microns \\
Coarse textured & More than 200 microns \\
\hline
\end{tabular}

\subsection{Wood working properties}

Wood working properties such as sawing, nailing, sanding and polishing were determined with the assistance of an experienced carpenter. Accuracy of the results was maintained by doing repeated tests. In order to obtain an idea of sawing ability, air seasoned, uniform thickened mature heartwood potions were also tested by the experienced carpenters. In order to depict data clearly, results were grouped into three categories as easy, moderate and difficult. For nailing, the air seasoned mature heartwood samples in dimensions of $132 \times 7.5 \times 12 \mathrm{~mm}$ were used. The nailing was done on cross section surface $13 \mathrm{~mm}$ interior to the border. Results were categorised into three groups as easy, moderate and difficult. Sanding data were obtained through number 320 sanding paper and results were categorized as very good, good and moderate. Final finishing property also classified as very good, good and moderate.

\subsection{Islandwide survey}

An Islandwide questionnaire survey was conducted to gather information from timber users who have experience on timber durability particularly using timber in outdoor uses.

\section{Results}

Table 3, 4, 5, and 6 present in the following sections illustrate all wood properties studied in this research work.

Table 3: Wood density and density property classes, modulus of elasticity, modulus of rupture and compression parallel to grain of the selected timber species.

\begin{tabular}{llccccc}
\hline No & Species & $\begin{array}{c}\text { Density } \\
\text { class }\end{array}$ & $\begin{array}{c}\text { Density } \\
\text { At } 12 \% \\
\mathrm{~m} . \mathrm{c} .\end{array}$ & $\begin{array}{c}\text { Modulus of } \\
\text { elasticity } \\
\left(\mathrm{Nmm}^{-2}\right)\end{array}$ & $\begin{array}{c}\text { Modulus of } \\
\text { rupture } \\
\left(\mathrm{Nmm}^{-2}\right)\end{array}$ & $\begin{array}{c}\text { Compression } \\
\text { parallel to } \\
\text { grain }\left(\mathrm{Nmm}^{-2}\right)\end{array}$ \\
\hline 1 & Acacia malanoxylon & $\mathrm{HD}$ & 738 & 11,811 & 90 & 45 \\
\hline 2 & Michelia champaca & LD & 500 & 8,503 & 64 & 32 \\
\hline 3 & Eucalyptus grandis & MD & 595 & 9,827 & 74 & 37 \\
\hline 4 & Alstonia macrophylla & HD & 690 & 11,150 & 84 & 43 \\
\hline 5 & Dipterocarpus zeylanicus & HD & 762 & 12,142 & 92 & 47 \\
\hline 6 & Bridelia retusa & VHD & 850 & 13,500 & 103 & 50 \\
\hline 7 & Khaya senegalensis & MD & 603 & 9,932 & 75 & 37 \\
\hline 8 & Azadirachta indica & HD & 714 & 11,481 & 87 & 44 \\
\hline 9 & Adina cordifolia & HD & 666 & 10,819 & 82 & 41 \\
\hline 10 & Artocarpus heterophyllus & MD & 625 & 10,250 & 78 & 39 \\
\hline
\end{tabular}




\begin{tabular}{llrrrrl}
\hline 11 & Terminalia arjuna & HD & 714 & 11,481 & 87 & 44 \\
\hline 12 & Homalium zeylanicum & HD & 738 & 11,811 & 90 & 45 \\
\hline 13 & Melia dubia & LD & 400 & 6,050 & 40 & 20 \\
\hline 14 & Swietenia macrophylla & MD & 609 & 10,025 & 76 & 38 \\
\hline 15 & Madhuca longifolia & VHD & 900 & 14,250 & 115 & 58 \\
\hline 16 & Eucalyptus microcorys & VHD & 875 & 13,719 & 105 & 53 \\
\hline 17 & Albizia saman & MD & 585 & 9,694 & 73 & 36 \\
\hline 18 & Hevea brasiliensis & MD & 540 & 9,059 & 68 & 34 \\
\hline 19 & Tectona grandis & HD & 720 & 11,550 & 88 & 43 \\
\hline 20 & Toona ciliata & LD & 500 & 850 & 60 & 30
\end{tabular}

* LD = Low density, MD = Medium density, HD = High density, VHD = Very high density.

Table 4: Wood working properties, seasoning and wood shrinkage in twenty timber trees.

\begin{tabular}{|c|c|c|c|}
\hline No & Scientific name & Seasoning \& shrinkage & Working properties \\
\hline 1 & Acacia malanoxylon & $\begin{array}{l}\text { Must be thoroughly seasoned. } \\
\text { Seasons well. Shrinkage green to } \\
\text { oven dry is } 6 \% \text {. }\end{array}$ & $\begin{array}{l}\text { Easy to work with hand and } \\
\text { machine tools. Excellent polishing } \\
\text { properties. Glues \& stains well. } \\
\text { Poor nailing. Splits easily \& pre- } \\
\text { boring is recommended. }\end{array}$ \\
\hline 2 & Michelia champaca & $\begin{array}{l}\text { Seasoning is not easy as the timber } \\
\text { is liable to split especially if left in } \\
\text { the log form. Shrinkage green to } \\
\text { oven dry is } 8.4 \% \text {. }\end{array}$ & $\begin{array}{l}\text { Easy to saw \& works to a smooth } \\
\text { surface. Good polishing. }\end{array}$ \\
\hline 3 & Eucalyptus grandis & $\begin{array}{l}\text { Difficult to season, Cupping may } \\
\text { occur in back-sawn boards, but can } \\
\text { be removed by reconditioning } \\
\text { treatment. Shrinkage green to } 10 \% \\
\text { moisture content is } 6.03 \% \text {. }\end{array}$ & $\begin{array}{l}\text { Young trees work easily. Old } \\
\text { material may produce certain } \\
\text { surface wooliness \& tendency to } \\
\text { split. Free from defects. Good } \\
\text { polishing. Tends to split in nailing. }\end{array}$ \\
\hline 4 & Alstonia macrophylla & $\begin{array}{l}\text { Green conversion \& immediate } \\
\text { seasoning give best results. } \\
\text { Shrinkage green to } 10 \% \text { moisture } \\
\text { content } 8.92 \% \text {. }\end{array}$ & $\begin{array}{l}\text { Sawing \& nailing are somewhat } \\
\text { difficult. Easy to sanding \& takes a } \\
\text { good polish. }\end{array}$ \\
\hline 5 & Dipterocarpus zeylanicus & $\begin{array}{l}\text { Seasoning is somewhat difficult. } \\
\text { Air drying is needed before kiln } \\
\text { drying. Shrinkage green to } 10 \% \\
\text { moisture content is } 6.63 \% \text {. }\end{array}$ & $\begin{array}{l}\text { Easy to sawing. Somewhat easy to } \\
\text { nailing. Easy to sanding \& finishing } \\
\text { is somewhat good. }\end{array}$ \\
\hline 6 & Bridelia retusa & $\begin{array}{l}\text { Seasons defects sometimes appear } \\
\& \text { hence green conversion \& } \\
\text { prompt stacking for slow drying is } \\
\text { recommended. Shrinkage green to } \\
10 \% \text { moisture content is } 5.45 \% \text {. }\end{array}$ & $\begin{array}{l}\text { Saws and machines well \& works } \\
\text { to a smooth surface. Easily worked } \\
\text { with hand tools. }\end{array}$ \\
\hline 7 & Khaya senegalensis & $\begin{array}{l}\text { Seasons well. Shrinkage green to } \\
10 \% \text { moisture content } 4.78 \% \text {. }\end{array}$ & $\begin{array}{l}\text { Easy to sawing, nailing \& sand } \\
\text { papering. Good finish when } \\
\text { polished. Filling materials should } \\
\text { be used. }\end{array}$ \\
\hline
\end{tabular}




\begin{tabular}{|c|c|c|c|}
\hline 8 & Azadirachta indica & $\begin{array}{l}\text { Seasons well. Shrinkage green to } \\
10 \% \text { moisture content is } 2.48 \% \text {. }\end{array}$ & $\begin{array}{l}\text { Somewhat difficult to sawing. Easy } \\
\text { to nailing \& sand papering. Poor } \\
\text { finish when polishing (good for } \\
\text { staining). }\end{array}$ \\
\hline 9 & Adina cordifolia & $\begin{array}{l}\text { Seasons well. Shrinkage green to } \\
\text { oven dry is } 10.2 \% \text {. Shrinkage green } \\
\text { to } 10 \% \text { moisture content is } 5.88 \% \text {. }\end{array}$ & $\begin{array}{l}\text { Easy to sawing \& sand papering, } \\
\text { slightly difficult to nailing, good } \\
\text { finish after polishing. }\end{array}$ \\
\hline 10 & Artocarpus heterophyllus & $\begin{array}{l}\text { Seasons easily. Shrinkage green to } \\
10 \% \text { moisture content is } 1.62 \% \text {. }\end{array}$ & $\begin{array}{l}\text { Easy to saw \& work. Finish well } \\
\text { particularly if fillers \& sealers are } \\
\text { used. Polish with a high lustre. }\end{array}$ \\
\hline 11 & Terminalia arjuna & $\begin{array}{l}\text { Seasons well. Should dry slowly. } \\
\text { Large timber prone to crack split \& } \\
\text { bend. Shrinkage green to } 10 \% \\
\text { moisture content is } 5.79 \% \text {. }\end{array}$ & $\begin{array}{l}\text { Difficult to sawing \& nailing. Sand } \\
\text { papering is easy. Good finish when } \\
\text { polishing. }\end{array}$ \\
\hline 12 & Homalium zeylanicum & $\begin{array}{l}\text { Somewhat difficult to seasons. } \\
\text { Shrinkage green to } 10 \% \text { moisture } \\
\text { content } 14.4 \% \text {. }\end{array}$ & $\begin{array}{l}\text { Saws and works easily. Takes a } \\
\text { good polish. }\end{array}$ \\
\hline 13 & Melia dubia & $\begin{array}{l}\text { Seasons easily. Shrinkage green to } \\
10 \% \text { moisture content is } 6.06 \% \text {. }\end{array}$ & $\begin{array}{l}\text { Easy to saw \& work, but difficult to } \\
\text { obtain a smooth finish on the } \\
\text { account of its softness. }\end{array}$ \\
\hline 14 & Swietenia macrophylla & $\begin{array}{l}\text { Seasons well \& easily without } \\
\text { much checking or distortion. Kiln } \\
\text { drying satisfactorily when moderate } \\
\text { scheduling. Shrinkage green to } 10 \% \\
\text { moisture content is } 2.93 \% \text {. }\end{array}$ & $\begin{array}{l}\text { Saws, planes \& moulds easily, } \\
\text { finish to a smooth surface. Wood } \\
\text { takes an excellent polish. Gluing \& } \\
\text { nailing are good. Discolorations in } \\
\text { contact with iron, copper \& brass. }\end{array}$ \\
\hline 15 & Madhuca longifolia & $\begin{array}{l}\text { Seasons well. If converted green, } \\
\text { log tend to split at the ends if left } \\
\text { unconverted. Shrinkage green to } \\
10 \% \text { moisture content is } 8.65 \% \text {. }\end{array}$ & $\begin{array}{l}\text { Sawing is somewhat easy. Difficult } \\
\text { to nailing \& easy for sand papering. } \\
\text { Good finish when polished. }\end{array}$ \\
\hline 16 & Eucalyptus microcorys & $\begin{array}{l}\text { Somewhat difficult especially with } \\
\text { fast grown timber. Shrinkage green } \\
\text { to } 10 \% \text { moisture content is } 9.77 \% \text {. }\end{array}$ & $\begin{array}{l}\text { Easy to saw. Difficult to nail, } \\
\text { sanding \& polishing. Difficult to } \\
\text { obtain a good polish. }\end{array}$ \\
\hline 17 & Albizia saman & $\begin{array}{l}\text { Seasons well. Shrinkage green to } \\
10 \% \text { moisture content is } 9.18 \% \text {. }\end{array}$ & $\begin{array}{l}\text { Easy to sawing, nailing \& sand } \\
\text { papering. }\end{array}$ \\
\hline 18 & Hevea brasiliensis & $\begin{array}{l}\text { Seasons well. Shrinkage green to } \\
10 \% \text { moisture content } 7.69 \% \text {. }\end{array}$ & $\begin{array}{l}\text { Easy to sawing, nailing \& sand } \\
\text { papering. Good finish when } \\
\text { polishing. }\end{array}$ \\
\hline & Tectona grandis & $\begin{array}{l}\text { Once seasoned "movements" are } \\
\text { very little. Shrinkage green to oven } \\
\text { dry is } 9.9 \% \text {. }\end{array}$ & $\begin{array}{l}\text { Not difficult to saw or work, but } \\
\text { care is need in working as the } \\
\text { timber is somewhat brittle. }\end{array}$ \\
\hline & Toona ciliata & $\begin{array}{l}\text { Seasons easily but radial checks \& } \\
\text { heart-shakes develop in the log. } \\
\text { Careful stacking is required to } \\
\text { prevent warping. Shrinkage green } \\
\text { to } 10 \% \text { moisture content is } 9.85 \% \text {. }\end{array}$ & $\begin{array}{l}\text { Saws \& works easily with good } \\
\text { finishing qualities. }\end{array}$ \\
\hline
\end{tabular}


Table 5: Durability of wood, wood texture and heartwood colour.

\begin{tabular}{|c|c|c|c|}
\hline & Scientific name & Durability & Heart wood colour and wood texture \\
\hline 1 & Acacia malanoxylon & $\begin{array}{l}\text { Durable. Resistant to } \\
\text { effective preservative } \\
\text { treatments. }\end{array}$ & $\begin{array}{l}\text { Brown or shaded of brown (IAWA). } \\
\text { Rich reddish brown to nearly black } \\
\text { banded with golden brown or red. Even, } \\
\text { medium to even textured. }\end{array}$ \\
\hline 2 & Michelia champaca & $\begin{array}{l}\text { Durable. Easy to medium } \\
\text { ability to apply preservative } \\
\text { treatments. }\end{array}$ & $\begin{array}{l}\text { Yellow or shaded of yellow (IAWA). } \\
\text { Light yellowish brown to olive brown. } \\
\text { Lustrous. Even \& medium textured. }\end{array}$ \\
\hline 3 & Eucalyptus grandis & $\begin{array}{l}\text { Moderately durable. } \\
\text { Somewhat difficult to apply } \\
\text { preservative treatments. }\end{array}$ & $\begin{array}{l}\text { Red or shaded of red (IAWA). White to } \\
\text { pink or light to dark red brown with a } \\
\text { pink tinge, depending on age and area of } \\
\text { origin. Medium or coarse textured. }\end{array}$ \\
\hline 4 & Alstonia macrophylla & $\begin{array}{l}\text { Moderately durable. Easy to } \\
\text { apply preservative } \\
\text { treatments. }\end{array}$ & $\begin{array}{l}\text { Yellow or shaded of yellow (IAWA). } \\
\text { No distinct heartwood. Cream colour. } \\
\text { Medium, even textured. }\end{array}$ \\
\hline 5 & Dipterocarpus zeylanicus & $\begin{array}{l}\text { Moderately durable. } \\
\text { Somewhat difficult to apply } \\
\text { preservatives. }\end{array}$ & $\begin{array}{l}\text { Red or shaded of red (IAWA). Light } \\
\text { pinkish brown on first exposure ageing } \\
\text { to reddish brown. Even \& coarse } \\
\text { textured. }\end{array}$ \\
\hline 6 & Bridelia retusa & $\begin{array}{l}\text { Durable. Difficult to apply } \\
\text { preservative treatments. }\end{array}$ & $\begin{array}{l}\text { Brown to shaded of brown (IAWA). } \\
\text { Dark to olive brown sometimes with } \\
\text { darker streaks. Medium \& fairly even } \\
\text { textured. }\end{array}$ \\
\hline 7 & Khaya senegalensis & $\begin{array}{l}\text { Moderately durable. Easy to } \\
\text { apply preservative } \\
\text { treatments. }\end{array}$ & $\begin{array}{l}\text { Red or shaded of red (IAWA). Even } \\
\text { pink colour to reddish brown (mahogany } \\
\text { brown). Medium \& coarse textured. }\end{array}$ \\
\hline 8 & Azadirachta indica & $\begin{array}{l}\text { Durable. Difficult to apply } \\
\text { preservative treatments to } \\
\text { heartwood. }\end{array}$ & $\begin{array}{l}\text { Red or shaded of red (IAWA). Red } \\
\text { when first exposed darkening to reddish } \\
\text { brown \& then resembling mahogany. } \\
\text { Medium to somewhat coarse textured. }\end{array}$ \\
\hline 9 & Adina cordifolia & $\begin{array}{l}\text { Moderately durable. Easy to } \\
\text { apply preservative } \\
\text { treatments. }\end{array}$ & $\begin{array}{l}\text { Yellow or shaded of yellow (IAWA). } \\
\text { Citron yellow when first exposed, } \\
\text { turning pale yellowish or reddish brown } \\
\text { with age. Fine and even textured. }\end{array}$ \\
\hline 10 & Artocarpus heterophyllus & $\begin{array}{l}\text { Durable. Resistant to } \\
\text { effective preservative } \\
\text { treatments. }\end{array}$ & $\begin{array}{l}\text { Yellow or shaded of yellow (IAWA). } \\
\text { Yellow or lemon yellow gradually } \\
\text { turning to a rich mahogany brown, very } \\
\text { old wood to a warm Vandyke brown. } \\
\text { Coarse textured. }\end{array}$ \\
\hline 11 & Terminalia arjuna & $\begin{array}{l}\text { Durable. Easy to apply } \\
\text { preservative treatments. }\end{array}$ & $\begin{array}{l}\text { Brown to shaded of brown (IAWA). } \\
\text { Olive brown streaked with dark blackish } \\
\text { lines. Coarse and even textured. }\end{array}$ \\
\hline 12 & Homalium zeylanicum & $\begin{array}{l}\text { Durable. Difficult to apply } \\
\text { preservative treatments. }\end{array}$ & $\begin{array}{l}\text { Brown to shaded of brown (IAWA). } \\
\text { Yellowish brown to yellowish red on } \\
\text { first exposure. Even \& fine textured. }\end{array}$ \\
\hline
\end{tabular}




\begin{tabular}{|c|c|c|c|}
\hline & Melia dubia & $\begin{array}{l}\text { Non-Durable. Easy to apply } \\
\text { preservative treatments. }\end{array}$ & $\begin{array}{l}\text { Red or shaded of red (IAWA). Light } \\
\text { pink to light red, when first exposed } \\
\text { ageing to reddish brown. Coarse \& } \\
\text { somewhat uneven textured. Subject to a } \\
\text { grey stain. }\end{array}$ \\
\hline 14 & Swietenia macrophylla & $\begin{array}{l}\text { Durable. Resistant to } \\
\text { effective preservative } \\
\text { treatments. }\end{array}$ & $\begin{array}{l}\text { Red or shaded of red (IAWA). Reddish, } \\
\text { pinkish, salmon coloured or yellowish } \\
\text { when fresh, darkening to deep red or } \\
\text { brown with age. Moderately fine to } \\
\text { rather coarse. }\end{array}$ \\
\hline 15 & Madhuca longifolia & $\begin{array}{l}\text { Durable. Difficult to apply } \\
\text { preservative treatments. }\end{array}$ & $\begin{array}{l}\text { Red or shaded of red (IAWA). Dull, } \\
\text { dark red, ageing to dull reddish brown } \\
\text { streaked with light brown lines. Coarse } \\
\text { \& even textured. }\end{array}$ \\
\hline 16 & Eucalyptus microcorys & $\begin{array}{l}\text { Durable. Resistant to } \\
\text { effective preservative } \\
\text { treatments. }\end{array}$ & $\begin{array}{l}\text { Yellow or shaded of yellow (IAWA). } \\
\text { Pale or yellowish brown or straw colour. } \\
\text { Moderately coarse \& even textured. }\end{array}$ \\
\hline 17 & Albizia saman & $\begin{array}{l}\text { Moderately durable. } \\
\text { Resistant to effective } \\
\text { preservative treatments. }\end{array}$ & $\begin{array}{l}\text { Brown to shaded of brown (IAWA). } \\
\text { Golden brown to dark brown. Coarse } \\
\text { textured. }\end{array}$ \\
\hline 18 & Hevea brasiliensis & $\begin{array}{l}\text { Non-Durable. Easy to apply } \\
\text { preservative treatments. }\end{array}$ & $\begin{array}{l}\text { Brown to shaded of brown (IAWA). } \\
\text { Difficult to distinct from the softwood. } \\
\text { White colour when first exposed, turn } \\
\text { into pale brown when ageing. Pink tinge } \\
\text { present. Coarse and even textured. }\end{array}$ \\
\hline 19 & Tectona grandis & $\begin{array}{l}\text { Durable. Difficult to apply } \\
\text { preservative treatments. }\end{array}$ & $\begin{array}{l}\text { Brown to shaded of brown (IAWA). } \\
\text { Golden brown which darkens with age. } \\
\text { Coarse and uneven textured. }\end{array}$ \\
\hline & Toona ciliata & $\begin{array}{l}\text { Moderately durable. Difficult } \\
\text { to apply preservative } \\
\text { treatments. }\end{array}$ & $\begin{array}{l}\text { Red or shaded of red (IAWA). Light } \\
\text { brick red when first exposed, ageing to a } \\
\text { rich reddish brown. Moderately fine \& } \\
\text { somewhat uneven textured. }\end{array}$ \\
\hline
\end{tabular}

Table 6: Uses twenty timber species.

\begin{tabular}{lll}
\hline No & Scientific Name & Uses \\
\hline 1 & Acacia malanoxylon & $\begin{array}{l}\text { Furniture, boats, cabinets, plywood, doors \& window frames, fittings in } \\
\text { banks, railway carriages, gun stocks, decorative works. }\end{array}$ \\
\hline 2 & Michelia champaca & $\begin{array}{l}\text { Reapers, ceiling spacers, door \& window sashes, partition frames, floor } \\
\text { boards, buildings, cheap furniture, valance boards. }\end{array}$ \\
\hline 3 & Eucalyptus Grandis & General construction, bridges, poles, posts, furniture, paneling, sleepers. \\
\hline 4 & Alstonia macrophylla & $\begin{array}{l}\text { General construction, toys, match-boxes, posts, cheap furniture, coffins, } \\
\text { carving, blackboards, transmission poles. }\end{array}$ \\
\hline
\end{tabular}




\begin{tabular}{|c|c|c|}
\hline 5 & Dipterocarpus zeylanicus & $\begin{array}{l}\text { Reapers, ceiling spacers, fascia boards, door frames, partition frames, } \\
\text { cheap furniture, treated sleepers, transmission poles, construction, under- } \\
\text { water work, piles, boards, scaffoldings, rafters, beams. }\end{array}$ \\
\hline 6 & Bridelia retusa & $\begin{array}{l}\text { Rafters, purlins, ridge hips, ceiling joists, wall plates, beams, reapers, } \\
\text { buildings, furniture, agriculture implements, drums, carts, cart shaft. }\end{array}$ \\
\hline 7 & Khaya senegalensis & Boxes, posts, light construction, ceiling boards, door \& window sashes. \\
\hline 8 & Azadirachta indica & $\begin{array}{l}\text { Furniture, paneling \& decorative work, rafters purlins, ridges hips, ceiling } \\
\text { joists, wall plates, reapers, buildings, panels, carvings, bottom of drawers. }\end{array}$ \\
\hline 9 & Adina cordifolia & $\begin{array}{l}\text { General utility timber, purlins, ridge hips, reapers, railing spacers, door } \\
\& \text { window sashes, furniture, carvings, fine turnery wood, ornamental } \\
\text { caskets, picture frames, brush-backs. }\end{array}$ \\
\hline 10 & Artocarpus heterophyllus & $\begin{array}{l}\text { House building, furniture, carriages, cabinet making, musical instruments, } \\
\text { boats, building, casks. }\end{array}$ \\
\hline 11 & Terminalia arjuna & $\begin{array}{l}\text { Beams, rafters, purlins, ridge hips, ceiling joists, wall plates, furniture, } \\
\text { construction, bridges. }\end{array}$ \\
\hline 12 & Homalium zeylanicum & $\begin{array}{l}\text { Beams, rafters purlins, ridges hips, ceiling joists, wall plates, flooring, } \\
\text { buildings, boats, oars, stair cases, brush backs, posts. }\end{array}$ \\
\hline 13 & Melia dubia & Ceiling boards, paneling \& packing cases, cigar boxes. \\
\hline 14 & Swietenia macrophylla & $\begin{array}{l}\text { Door \&window frames, partition frames, furniture, cabinets, paneling \& } \\
\text { decorative work, railway carriages, piano cases, veneers. }\end{array}$ \\
\hline 15 & Madhuca longifolia & $\begin{array}{l}\text { Heavy construction, agricultural implement, reapers, ceiling spacers, door } \\
\& \text { window frames, partition frames, heavy construction, posts, beams, } \\
\text { boats, bridges. }\end{array}$ \\
\hline 16 & Eucalyptus microcorys & $\begin{array}{l}\text { Piles, poles, posts, flooring, sleepers, transmission poles, heavy } \\
\text { construction work, excellent for dance floors. }\end{array}$ \\
\hline 17 & Albizia saman & $\begin{array}{l}\text { Beams, rafters, purlins, ridges hips, ceiling joists, wall plates, furniture, } \\
\text { paneling, flooring. }\end{array}$ \\
\hline 18 & Hevea brasiliensis & $\begin{array}{l}\text { Partition frames, ceiling boards, furniture, light construction, brush } \\
\text { handles. }\end{array}$ \\
\hline 19 & Tectona grandis & $\begin{array}{l}\text { Ship building, high class joinery, flooring, interior fittings, door \& } \\
\text { windows frame \& sashes, stair cases, fancy goods, veneers, railway } \\
\text { carriers, beams, rafters purlins, ridges hips, ceiling joists, wall plates, } \\
\text { reapers, ceiling spacers, furniture, railway carriages. }\end{array}$ \\
\hline 20 & Toona ciliata & Furniture, paneling, cigar boxes, racing boats, musical instruments. \\
\hline
\end{tabular}

\section{Discussion}

It can be understood that when popular or well known timber is not available or not affordable due to high cost, another timber species is sought often on the basis of comparability with that formerly used. In this timber selection process, the cost involved is often considerable and users may be reluctant to face risk accepting the unknown timber species. This situation can be altered by providing guidance on property needs for the appropriate to end-use. The end-use property classification given in this paper provides the means to make an objective assessment of the suitability for a particular purpose of timber use. However, this suitability of timber depends on the combined cost of the selected timber and additional cost involved for processing (e.g. 
preservation). This cost is compared with the cost of a timber which is not required for additional processing.

Thelandersson \& Hansson (1999) stated that wood has significant variations in its properties both between and within timber elements. Variations in strength properties may be species-specific, age-dependent and environmentally responsive. Therefore it is suggested to conduct more research work in this field based on more timber samples representing of the entire population.

Understanding physical properties, mechanical properties, durability and gross features of various timber species are very much important in selecting timbers for various purposes. Correct use of timber always increases the life time of the final product, whether it is high class furniture or a simple craft work. This paper provides most important wood properties facilitating to select timber species according to end-use or end use requirement of twenty Sri Lankan timber species.

In general, the proposed property classification in this paper can be categorised as (i.) end-use property classification for building construction, (ii.) end-use property classification for furniture and joinery (iii.) end-use property classification for light construction and (iv.) end-use property classification for miscellaneous uses. It is an imperative exercise to find out the most influential wood properties for each category of end use property classification given here with.

Very high density timber such as Madhuca longifolia and Eucalyptus microcorys, studied in this research work are often chosen for heavy construction work due to not only its high strength property but also good performance experience in use for centuries. It was found that timber density of $M$. longifolia and E. microcorys are $900 \mathrm{kgm}^{-3}$ and $875 \mathrm{kgm}^{-3}$ at $12 \% \mathrm{~m} . \mathrm{c}$ respectively. In addition, both species showed high values of mechanical properties such as modulus elasticity, modulus of rapture and compression parallel to grain (Table 3). Both timber species demonstrated effective resistant to boron treatment when application of preservatives was done. Furthermore, results of grave yard test showed that both timber species can be classified as durable timber. As far as wood working properties are concerned, sawing is easy and nailing is difficult for both species. Working properties like sanding and polishing did not demonstrate such similarity in M. longifolia and E. microcorys. These finding might be used to define the standard for quality requirement and quality level for end-use property classification for construction timber. In this classification, some important quality requirements like seasoning defects, dimensional movement etc. can also be included for further improvement. Further it is recommended that preferable property level of timber for major end-uses should be studied in future research.

End-use property classification for furniture and joinery category which involves end-use products like window joinery, door and window frames, flooring and cabinet work etc. can be derived for the construction timber category mentioned in the earlier section. Acacia malanoxylon, Adina cordifolia, Artocarpus heterophyllus, Terminalia arjuna, Swietenia macrophylla, Tectona grandis and Eucalyptus grandis have proven timber quality complying with technical requirements, needed for end-use category of furniture and joinery. When variations of timber density of furniture and joinery category were analysed it was found that all the species can be categorised as medium to high density. This group of timber has somewhat lower density than to construction timber category. Results in Table 4 show that the timber in this category seasons well and demonstrated comparatively better working properties than those in 
the construction category. According to IAWA (1989) classification, the heartwood colour of furniture category timber consists of different wood colour. A. malanoxylon, T. arjuna and $T$. grandis have brown or shaded brown colour and S. macrophylla and E. grandis have red or shaded red colour followed by A. cordifolia and A. heterophyllus with yellow and shaded yellow. According to this finding, property requirements and level for the end-use classification for furniture and joinery might be derived from these research findings and further development can be made with increased number of timber species. In this direction, we have initiated a research program to collect wood properties of 235 Sri Lankan timbers. The publication of "Sri Lankan timber: Timber properties and its uses" covering 100 timber species is now in the press and it will be helpful to those who are willing to continue research in this regard.

Among many timber varieties used for light construction work in Sri Lanka, $M$. champaca, M. dubia, T. ciliate and H. brasiliensis are the most popular timber species. It can be assumed that wood properties in this study might influence mainly for the end-use application. Therefore by recognising these influential wood properties, it was possible to list out major property requirements and level for end-use property classification. According to Table 3, all the above timber species belong to light to medium density categories and having low mechanical properties. Both $H$. brasiliensis and $M$. dubia are non-durable and both timber can be preserved easily. According to the results of the boron treatment (Table 5), M. champaca and T. ciliate were classified as easy/medium category and difficult category respectively. All three species which were tested for working properties showed almost similar results indicating that working properties such as sawing and nailing are easy. Major property requirements for end-use property classification for light construction can be identified by these results.

End-use property classification for miscellaneous uses might be developed for the specific end-use application. For instance, $M$. longifolia timber is perfect for storing boxes of paddy seeds or container because this timber is capable to repulse pests or insects that use to come and destroy the paddy yield.

Some timber species such as $B$. cordifolia is highly demanded for manufacturing of vats. It is believed that $B$. cordifolia timber can enhance the quality of liquor by absorbing unfavorable matters and improve the taste and smell. Timber like $B$. retusa and $V$. pinnata possess special wood quality which helps to persist the timber in ground contact environment without getting deterioration. D. zeylanicus is eminently suitable for under-water work. E. microcorys is regarded as one of the best timber for dance floors. This specialty and causative factors of timber must be explored and documented in order to prepare end-use property classification for miscellaneous use.

Finally, if there is a timber property classification, i.e., requirement and property level for major end-uses as discussed in this paper and comprehensive information on wood properties of Sri Lankan timbers is available, then the timber industry will be able to define the technical information of timber which they need for their end-use applications. Subsequently the timber supplier can easily quote and supply the most suitable timber variety which is complying its technical performance with the requirement of end-use. 


\section{References}

Hatharasinghe, S.M., 2013. Community awareness of timber in Sri Lanka. BSc Dissertation, University of Ruhuna, Sri Lanka.

IAWA committee (1989). IAWA list of microscopic features for hard wood identification. IAWA Bulletin (N.S.)10, Netherlands.

Ruwanpathirana, N.D., 2012. Sustainable utilization of timber resources in Sri Lanka. SOBA, Ministry of Environment, Sri Lanka, pp.56-70.

Ruwanpathirana, N.D, 2014. Sri Lankan timber species: Wood properties and its uses, Ministry of Envirnment, Sri Lanka.

Thelandersson, S., Hansson, M., 1999. Reliability of timber structural system-effects of variability and inhomogeneity. Lund University of Technology, Sweden.

Withana, M. H., 2013. Classification of timber species in Sri Lanka and developing a model for price determination. BSc Dissertation, University of Ruhuna, Sri Lanka

www.timber.lk (forestry education web site), 100 timber species in Sri Lanka. Accessed $15^{\text {th }}$ May 2014. 